\title{
Annäherung Jupiters an einen Fixstern. Die Finsterniss am 31. Dec.
}

Am 20. Nov. beobachtete ich Jupiter als er nahe dem Ich bemerkte ein scheinbaresZuruickschieben eines Sonnen. Stern B. D. $+2^{0} 97$ vorbeiging, und nach mikrometrischer flecks vor dem vorrückenden Mond, um dessen Rand Messung war er nur 4 "O5 von dem Stern entfernt. eine Schnur von äusserstem Glanz, wie der Schaum Es war eine seltsame und sehr schöne Ansicht - Jupi- vor dem Bug eines Schiffes, wahrgenommen wurde.

ter mit fünf Trabanten! Das Licht des Sterns war doch von dem der Satelliten sehr verschieden, und erschien, anstatt $7^{\mathrm{n}} 7$, nur $10^{\mathrm{m}}$, nahe dem Glanz der grossen Scheibe.

Die Sonnenfinsterniss wurde hier nicht gut gesehen.

Die nördlichen Gegenden Jupiters scheinen jetzt mit stets zunehmenden Banden verschattet.

Millbrook, Tuam, I88I, Jan. I4.

\section{Fohn Birmingham.}

\section{Diametro di Vesta (vedi A. N. 2332).}

Nel numero 2332 delle A. N. diedi un valore del altre ro misure, che non erano state fino ad ora calcolate. diametro di Vesta $=1 " 706 \pm 0$ "09; questo valore risultava $S i$ ha da questa serie 1 " $436 \pm 0$ " 18 , e quindi il valore da varie misure operate con un oculare di ingrandimento 1000. Rifacendo il Prof. Millosevich i suoi calcoli trovò una piccolissima differenza di $0^{\prime \prime} \mathrm{O}_{\mathrm{I}} \mathrm{I}$, per cui il nuovo valore basato su 12 misure è $\mathrm{I}^{\prime \prime 6} 65+0^{\prime \prime 09}$. Il 9 Giugno feci anche con un altro ingrandimento (700)

compensato sarebbe, tenuto conto d'ambedue le serie, $A=\mathrm{I}^{\prime \prime} 62$, ed alla distanza uno $=\mathrm{I}^{\prime \prime} 4 \mathrm{I}$.

Roma 29 Gennajo I 88 I.

\section{$0 \Sigma 547$}

This pair, the last number of the Pulkowa Catalogue, $\mid \begin{array}{lllll}\beta & P=114^{\circ} 9 & D=4^{\prime \prime} 47 & \text { I } 880.73 & 4 \text { nights }\end{array}$ promises to be as interesting as the corresponding number of the Dorpat Catalogue, $\Sigma 547$. According to $O \Sigma$, it has an annual proper motion of $I^{\prime \prime}$. It was first measured at Pulkowa in I874, and subsequently twice in 1876 . Dembowski also measured it in 1875 . It is an easy pair, the components being of nearly the eighth magnitude, and within the reach of a very moderate aperture. I have recently made a series of measures as follows:

$$
\begin{aligned}
& P=\text { II } 5^{\circ} 3 \quad D=4^{\prime \prime 65} \quad \text { I } 880.7 \mathrm{I} \\
& \begin{array}{lll}
114.7 & 4.38 & 72
\end{array} \\
& \begin{array}{lll}
113.9 & 4.54 & 73
\end{array} \\
& \begin{array}{lll} 
& 115.7 & 4.30
\end{array}
\end{aligned}
$$

The mean results of the several sets of measures are:

$$
\begin{aligned}
& A P=110^{\circ} 8 \quad D=4 \text { "13 } 1875.832 \text { nights. }
\end{aligned}
$$

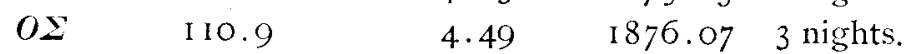

These observations show clearly that the components have a common proper motion; and furnish some evidence of angular movement, leaving but little doubt of the physical relation of the stars. The principal star is Lalande 47.231 and its place: R. A. $23^{\mathrm{b}} 59^{\mathrm{m}}$; Jecl. $+45^{\circ} 9^{\prime}$.

While measuring this system, I found a new pair about $25^{\circ}$ pr. and $8^{\circ} \mathrm{s}$, and closely resembling $O 2547$ in distance and magnitudes. The result of four measures gives:

$$
P=339^{\circ} 7 \quad D=4^{\prime \prime O} 2 \quad \text { I } 880.73 .
$$

This is Lalande 47.215 . The components are a little more unequal, being about 7.8 and 9.0 magnitudes.

Chicago Jan. Io, I88I.

\section{S. W. Burnham.}

\section{¿ 430 (Tani 39).}

This pair has been regarded as having relative motion, and is given in Flammarions Catalogue of double stars in motion, the change being in the most distant of the two companions. I have made a careful series of measures on four nights, the mean result of which $\beta$ is given below. The following are all the measures of

$\mid \begin{array}{lrrrr}\Sigma & A \text { and } B . \\ M a & P=55^{\circ} 3 & D=26^{\prime \prime} 57 & 1831.23 & 3 \text { nights } \\ 54.9 & (25.49) & 1843.53 & 1 \\ A & 55.7 & 26.16 & 1863.12 & 2, \\ \beta & 55.5 & 26.11 & 1879.08 & 4,\end{array}$
this System: 


$$
\begin{array}{lrrrr}
\multicolumn{9}{c}{A \text { and } C} \\
\Sigma P=301^{\circ} 9 & D=39^{\prime \prime} 40 & 1831.23 & 3 \\
A & 301.2 & 37.74 & \text { nights } \\
\beta & 300.9 & 37.72 & 1879.08 & 4
\end{array}
$$

An inspection of these observations will show that there must be some error in Struve's distance of A C; and I have no doubt if the original observations are examined, there will be found a mistake in copying or printing. The correct distance will perhaps be found to be $37^{\prime \prime} 40$. In that case, the slight change in the angle of $C$ would almost exactly correspond to the diminution in the distance of $B$ since Struve, resulting from a small proper motion of the principal star.

Chicago, Dec. 17. 1880.

\section{S. W. Burnham.}

\section{Beobachtungen des Cometen $f 1880$ (Pechüle).}

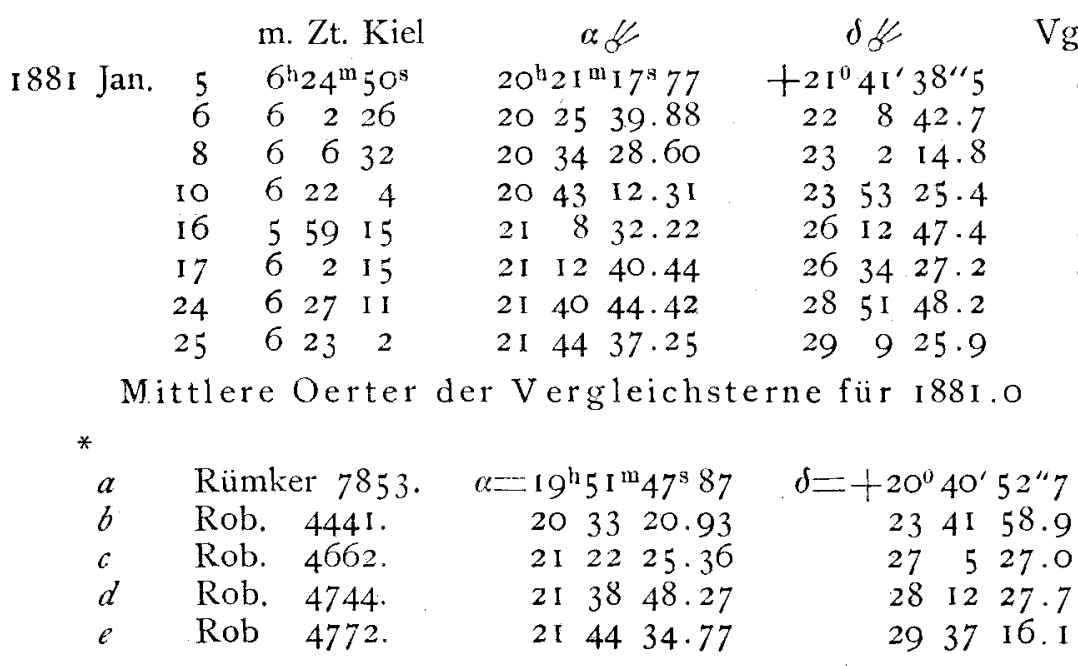

Kiel, 188I Februar 15.

C. F. W. Peters.

\section{Literarische Anzeigen.}

Klinkerfues'sche Neue Constanten zur Reduction auf den scheinbaren Ort, berechnet von H. Kobold. Dr. phil. Veröffentlicht von der Sternwarte O'Gyalla in Ungarn.

Diese Tafeln geben für jeden Tag des laufenden Jahres die auf Grund des s Nautical Almanac for the year I $88 \mathrm{I}$, berechneten Werthe fuir die Constanten $K, L, \log k, \log l, f$ und $i$. Die beiden letzteren bedeuten dasselbe, wie die gleich bezeichneten Grössen des Nautical Almanac, die Bedeutung der anderen in der Bezeichnung des Naut. Alm. ist aus folgenden Formeln ersichtlich:

$$
\begin{array}{ll}
2 k \sin K=A+D & 2 l \cos L=A-D \\
2 k \cos K=B+20.0537 C & 2 l \sin L=-B+20.0537 C .
\end{array}
$$

Die Reduction auf den scheinbaren Ort ist dann bei Einfuihrung der halben Poldistanz $\frac{p}{2}$ so:

$$
\begin{aligned}
\Delta \alpha & =f+k \cot \frac{p}{2} \sin (K+\alpha)+l \operatorname{tg} \frac{p}{2} \cos (L+\alpha) \\
\Delta \delta \sec \delta & =i+k \cot \frac{p}{2} \cos (K+\alpha)+l \lg \frac{p}{2} \sin (L+\alpha) .
\end{aligned}
$$

Auch die Werthe $\operatorname{tg} \frac{p}{2}$ und $\cos \delta$ sind in einer Tafel, deren Argument die Declination ist, gegeben. Der Verfasser bittet nachträglich anzumerken, dass die berechneten Constanten für I 2 Uhr mittlere Berliner Zeit gelten; das Heft selbst enthält aus Versehen keine Notiz daruber. 